\title{
Power Dialectics and the Crisis of Identity in Anglophone Cameroonian Poetry: The Poetic Vision of Gahlia Gwangwa'a and Bate Besong
}

\author{
Andrew T. Ngeh, PhD \\ University of Buea- Cameroon, Cameroon \\ E-mail: ngehandrew@yahoo.com \\ Usman Suleiman \\ Umar Suleiman College of Education, Gashu'a, Yobe State, Nigeria \\ E-mail: baturiya81@yahoo.co.uk
}

Received: January 23, 2014 Accepted: May 20, $2014 \quad$ Published: July 17, 2014

doi:10.5296/jsss.v2i1.5988 URL: http://dx.doi.org/10.5296/jsss.v2i1.5988

\begin{abstract}
The concept of power dialectics in African literature accounts for the tension, contradiction and confusion that have resulted in identity crisis, alienation and social exclusiveness. Guided by the socialist realism of the Lukacsian-Marxist paradigm, this paper contends that the power dialectics in the Cameroonian society is responsible for the crisis of identity, alienation and social exclusion. In trying to recreate poetry that tyrannizes the spirit, Gwangwa'a and Besong construe that only the destruction of totalitarianism and neocolonialism can usher in justice, equity, equality, democracy and a sense of belonging in a society bedeviled by corruption, tribalism, dictatorship and moral decadence.
\end{abstract}

Keywords: Power, Dialectics, Identity and Social Exclusion 


\section{Introduction}

The concept of power dialectics in African literature accounts for the tension, contradiction and confusion that have resulted in identity crisis, alienation and social exclusion. During the nationalist struggle in the late 1950s and early 1960s the African masses, African politicians and African writers came together against their common enemy- the white man. The impression created at the time was that the colonial ruler was solely responsible for their predicament, plight and sufferings. During this quest for a nation, nationalism was misconstrued as an ideology. They would later on be disproved because the basis of this quest was the camaraderie of the skin. In other words, nationalism is not an ideology because it falsely appeals to the camaraderie of the skin. When power finally left the colonial rulers for the Africans, the situation only moved from bad to worse. The masses became socially excluded from the socio-political and economic affairs, marginalized and economically exploited. In this regard, the masses and writers started looking for alternative means of survival. While the ruling class uses its own power to oppress and subjugate those with dissenting voices and opinions, the oppressed masses' reaction is somewhat violent. This power dialectics and dynamics from the two classes constitute the power conflict in African literature.

It is from this standpoint that revolutionary and radical Anglophone Cameroonian poets like Gahlia Gwangwa'a, Bate Besong, Nol Alembong, Emmanuel Fru Doh, Mathew Takwi and John Ngong Kum Ngong write. They write with the conviction, consciousness and orientation that if something is not done, society will slowly but surely drift to the precincts of insanity. The radicalism and the rhetoric of violence exhibited in their poetry attest to this. From this perspective, this paper contends that Gwangwa'a and Besong in their respective collections, Cry of the Destitute (1995) and Disgrace: autobiographical narcissus, (2007) demonstrate that the power dialectics evident in the Cameroonian body politic has resulted in identity crisis, alienation and social exclusion. The poets express anger and frustration which culminate in the rejection of the neocolonial political systems that have reduced the masses to Sisyphean existence.

\section{Operationalism}

For the sake of clarity and comprehension, it is important to define some key concepts. This is in keeping with Bernard Fonlon's suggestion in "The Idea of Literature" that the first principle of any scientific discourse is the definition of one's terms or concepts so as to know "clearly and precisely right from the start" what these terms or concepts mean (179). These terms are: power, dialectics and identity. Power according to the Oxford Universal Dictionary Illustrated is the "ability to do something or anything or to act upon a person or thing" (1559). But within the context of this paper, power is viewed from the perspectives of social, political and economic control. That is how people who possess power use it to influence and control others socially, politically, economically and culturally.

Dialectic is the second term worth defining in this article. Dialectic is derived from a Greek word which means "to carry on a discussion". Statement, (thesis) and counterstatement, (antithesis) may give rise to a certain conclusion, (synthesis). Under favorable conditions the conclusion can be considered as belonging to a higher level, (synthesis). According to The 
Oxford Universal Dictionary Illustrated, dialectic "is the art of critical examination into the truth of an opinion ... a synonym of Logic as applied to formal rhetorical reasoning; logical disputation" (500) The same source adds that dialectics is the criticism which shows the mutually contradictory character of the principles of science when employed to determine objects beyond the limits of experience (500). The omnipresence of the dialectic principle has been emphasized in most contemporary literature, which views the dialectic as the theory of progress and development. In this paper, the two types of power exerted and exercised by both the oppressors and the oppressed are dialectically related. In dialectics, there is thesis, antithesis and synthesis. That is, while the oppressors use power to dehumanize the oppressed, (thesis) the power exercised by the oppressed frees both the oppressed and the oppressors (antithesis and synthesis). This is where the power dialectics and the quest for social space reside. And this is the perspective and standpoint of this article.

Finally, identity is another term worth defining. Cambridge Advanced Learner's Dictionary defines identity as a person or group which makes them different from others (762). In this article, identity has to do with cultural, political and social exclusion. Because the masses are socially isolated and politically marginalized, the quest for their identity as humans with inalienable rights and freedom becomes a categorical imperative.

\section{Research Problem}

The fundamental problematic addressed in this paper is the Western notion and conception of literature/poetry not being change-oriented. If among western scholars and writers commitment in art is a dispensable issue, among Anglophone Cameroonian writers/poets, it is an indispensable reality. This study, therefore, debunks art for art's sake and recommends art that is functional; that is, art that is duty- bound to make the world better. Thus, good poetry is politically on the side of the oppressed. From this standpoint, the following questions provide a searchlight for this article:

What is the relationship between power and cultural identity?

What is the link between power dialectics and nation building?

What is the relationship between the rhetoric of violence and nation building?

How has the use of power contributed to social exclusion and alienation in the Cameroonian nation?

In view of the problem as stated above and the questions as posed, this paper hypothesizes that the concept of power dialectics in Anglophone Cameroonian literature accounts for the tension, contradiction and confusion that have resulted in identity crisis, alienation and social exclusiveness. It is, therefore, the contention of this study that the abuse and misuse of power by the comprador bourgeoisie class has created friction in the Cameroonian society, and this has resulted in alienation, social exclusion and the sense of not belonging.

\section{Theoretical Considerations}

This article is informed by the socialist realism of the Lukacsian-Marxist paradigm. The concept of socialist realism marks an important advance in the development of Marxist aesthetics on literature and art in general. Socialist realism according to http://www.l.evengenvaertcentre.be/ is a soviet artistic doctrine, realistic in its nature which has a purpose the furtherance of the goals of socialism and communism. Basically, some of 
the features of socialist realism include: optimism and hope, conscientisation and revolt. Chidi Amuta in The Theory of African Literature outlines the following characteristic features of socialist realism. He contends, “... the essential attributes of socialist realist expression include(a) the use of simple and accessible language (b) a sympathetic portrayal of characters from the oppressed,(c) a sense of patriotism defined in terms of concern with the struggle of socialism"(140). Socialist realist writers must be politically active on the side of the oppressed.

Maxim Gorky, the doyen of socialist realism summarizes these socialist realist features thus:

... it is clear that in addition to the necessity of studying the language and developing the ability to select the simplest, most graphic and colourful words from a literary language, which while perfected to a high degree is nevertheless littered with empty and ugly words, the writer must also have a good knowledge of the past history and of the social phenomenon of contemporary society in which he is called upon to fulfill his dual role of midwife and grave-digger (32-33)

Finally, Es'kia Mphahlele contends that African writers especially critics must always "hammer their theories out of their social realism" (84).

The aim of Marxism is to bring about a classless society, based on the common ownership of the means of production, distribution and exchange. Marxism is a materialist philosophy: that is, it tries to explain things without assuming the existence of a world or of forces beyond the natural world around us and the society we live in (Peter Barry, 156). The antithesis of Marxism is idealism. Marxist philosophy is materialist based. According to Maynard Solomon, Marxism is the symbolism of dialectical conflict, of drama, of the unity of opposite, of revolutionary change, of matter and man in motion, constantly transcending the moment, pointing into the future (qtd in Chidi Amuta, 52). All these articulations point to one thing: that whereas other philosophies merely seek to understand and interpret the world, (critical realism), Marxist criticism like socialist realism seeks to change it. The power dialectics exhibited in Gwangwa'a and Besong's poetic vision is essentially meant to usher in change for the better.

There were various influences on early Marxist thinking in addition to that of the political experiences of its founders, including the work of eighteenth-century German philosopher, Hegel especially his idea of dialectic, whereby opposing forces or ideas bring about new situations or ideas. These two opposing forces are the Base and the Superstructure representing the ruled and the rulers respectively. Marxism, therefore, is built on socialist realist thinking.

Marx and Engels who were the brain behind Marxism applied the dialectic principle mainly to the sphere of social development. They believed that the class struggle between the bourgeoisie and the proletariat would lead inevitably to the overthrow of capitalism, thus promoting the cause of social progress (Fokkema \& Ibsch, 1995:83).

\section{Discussion and Analyses}

Using the Marxist critical theory and the concept of socialist realism for the interpretation and evaluation of this paper, the motivating factor is to attempt to proffer the possibilities for a rigorous materialist interpretation and reading of Gwangwa'a and Besong's poetry. In this 
regard, the contradictions that have bedeviled the socio-political, economic, historical and cultural lives of Cameroonians become the focal point. Thus, the discussion of this paper is done under three thematic clusters: Power Dialectics and the Quest for Identity; Power, Alienation and Social Exclusion and The Rhetoric of Violence and Nation-building.

\section{Power Dialectics and the Quest for Identity}

"The African politician is a blind man: he moves only in one direction- toward himself". (Nuruddin Farah, 1983:11)

The acquisition of power in most contemporary African societies is a veritable Trojan horse as the leaders acquire power to insidiously intimidate, frustrate, subjugate and oppress the very people who legitimize this power. Since the ruling class perceives power as a license to plunder and swindle state funds, the reaction of the ruled is somewhat violent. While the ruled think that the wealth of the nation belongs to all and should be equally distributed, the rulers think that the nation's wealth belongs to them. The marginalization and subjugation of the masses have made them to ask questions about their being, essence, existence and identity. Gahlia Gwangwa'a in "Politics Inside" and Bate Besong's "Appointments in UB" have succinctly articulated the above-mentioned themes.

In Gwangwa'a's "Politics Inside", the poet demonstrates that the dialectics of power structure as reflected in African poetry is deeply rooted in African history which characterizes the African reality. The poem "Politics Inside" captures the hypocrisy and double-speak of the neocolonial elites in contemporary Africa. The politicians visit their constituencies only when elections are around the corner. 'Politics inside' as opposed to 'politics outside' is a dangerous brand of politics practiced in contemporary Africa. It is politics that thrives on egocentrism, self-centeredness, vacuous rhetoric and selfishness. 'Outside politics' is that which goes right to the people and addresses their problems:

Quite often several mouths

Went out to places to scout

Votes for impending elections

Not without their stomachs predilections. (33)

The poet/persona debunks the self-centeredness of these neocolonial rulers whose stomachs have become their political compass. Material prosperity and spiritual bankruptcy characterize the lives of these politicians. He concludes that the masses will become conscious only if they refuse to sell their consciences during political campaign periods for a tablet of savon or a bottle of beer:

Whoever stands on the way

Causes sleeves to fold aback

For effective fists sway

To receive pernicious kick backs

When to feed no more

Let the stomach reason

While the brain does the digestion

And refuse not the inside to call for more. (33) 
The poet thinks that the masses can only be politically active if they are adequately educated and conscientised; and it is only when they are conscientised that they can start questioning the excesses of the ruling class. Andrew Tata Ngeh in "Socialist Realism and the Dialectics of Violence in Anglophone Cameroonian Drama: Bate Besong and Bole Butake's Dramatic Vision" contends that "... the need for a violent and radical intervention of the people in confronting an oppressive system is the only means that can usher in liberty, freedom and democracy" (2012:103). The present study borrows a leaf from this argument and stretches its tentacles further as the common man has to sacrifice certain pleasures and leisure for the attainment of liberty and democracy.

This campaign period is time for the politicians to eat and drink from the money meant to convince, deceive and cajole the cynical masses. The poet adumbrates and imbricates the greed and epicurean nature of these politicians. As they use campaign money on food and drinks, the masses languish in abject poverty. The poet states:

Carrying along sharpened teeth

Exhibit of the tongues impatience, for no meat

Shows up in any plate without being crushed

Nor a good wine with which to flush. (33)

The images of "sharpened teeth" and "tongues impatience" are very frightening. They depict the politicians as very greedy people.

Like Gwangwa'a, Besong's thinking is also characterized by the dialectics of power structure which sees the world as being in a constant state of motion, progressing from lower to higher levels of existence. His world like that of Gwangwa'a is not a static one. This is the very basis of Bate Besong's argument in this poem entitled "Appointments in UB".A writer writes best about the environment he knows best. This particular poem is written by a member of the intelligentsia using revolutionary language to debunk the ills that characterize appointments in the academia. Lecturers have abandoned academics and are in pursuit of administrative positions. The rationale behind the acquisition of this power is to frustrate, oppress and intimidate colleagues with dissenting voices. They are no longer trust worthy because there is no difference between good and bad. Lecturers cum administrators have distorted and mystified the truth as there is no clear distinction and demarcation between good and bad.

The abbreviation, "UB" in this poem stands for the University of Buea. When the University of Buea was created by a Presidential decree in 1993, the popular slogan for this institution of higher learning was "UB, the Place to Be." Before his demise in a ghastly motor accident on the 8th of March 2007, Bate Besong taught in that institution and was a victim of the oppressive administrative machinery that was/is in place. The poet is worried and even perturbed that even those Lecturers who were victims of oppression and who have now joined the rank of the oppressors are also oppressing their own colleagues. The poet sees this as a contradiction that is counter-productive. In "Appointments in UB", the poet writes:

These prisoners who have now

become numbers

in the Gaullist galley 
system where Good is Bad and

Bad is Good.

I speak of yesterday's undesirable

lecturers, whose

rheumy psyche still

bear the scars of occult-

Cannibalism

in an academy, constructed,

on the muzzling

of dissident voices

where the sword and

the bullet hold unmitigated

sway

and the dead heroes of the

Uprising. (22)

Lecturers are depicted and portrayed in this poem as schemers and traitors. They are more position-driven than research- oriented. This is a poem which has both a specific reference to the University of Buea, and possibly, a wider frame of reference to the other institutions of higher learning in Cameroon where lecturers with dissenting voices are muzzled, gagged and victimized. In this regard, mediocrity takes precedence over meritocracy. The poet decries nepotism and tribalism in appointments in institutions of higher learning in Cameroon. Because appointments are based on who you know and not what you know, excellence and meritocracy are compromised and mediocrity is celebrated and glorified. This is the ultimate imponderable dialectics over which tragic poetry builds its symbolic edifice. Committed and conscientious lecturers with dissenting voices are not given any post of responsibility. The poet is worried:

I write of yesterday's

Campus philosophers, who

Now, lock themselves up in their cells, inside

Their mbag'alung hives

They are happier living with the dead

Material things have only fleeting value. (24)

The 'mbag'alung' hive is a metaphor of tribalism, nepotism and favoritism. This is the forum where the University hierarchy meets to decide who will be appointed in which position. Etymologically, mbag'alung is a cultural and traditional dance in some parts of the North West Region of Cameroon, specifically, Mankon, Bamendakwe and Nkwen. The poet insinuates that appointments in state owned Universities in Cameroon are based on tribalism and one's loyalty to the ruling party, the Cameroon People's Democratic Movement 
(C.P.D.M). In using poetry as a historical necessity, the poet construes that the erosion of state legitimacy is what might have compelled authoritarian and neocolonial politics to get into the academia.

The poet also indicts some leaders of SYNES (Syndicat National des Enseignants du Superieur) who have sacrificed and betrayed the collective struggle of oppressed lecturers in Cameroon for their personal and material gains:

Materialistic pursuits

Govern the lives

Of yesteryears trade

Union leaders, whose

Programmed slave

Consciousness has been,

Wrought;

By the madmen

and specialists of home-

Guard psychology. (23)

The poet uses a plethora of images to reinforce the fact that the argument of force and not the force of argument permeates and pervades the administration of the University of Buea. Lecturers with different opinions have had very difficult times with successive Vice-Chancellors in the University of Buea. Those with critical minds and alternative vision are stifled and muzzled. The apogee of this persecution and victimization of lecturers was in May 2013 when Dr Pauline Nalova Lyonga Egbe, the serving Vice Chancellor of the University of Buea ordered for the arrest and detention of ten Lecturers for "terrorism, sedition and inciting students to violence". The Lecturers in question were: Professor Jonie Fonyam, Professor Michael Yanou, Professor Molem Sama Christopher, Dr Fontem Neba, Dr Martin Sango, Dr Andrew Tata Ngeh, Dr Richard Agbor, Dr Henry Muluh, Dr Victor Banilon and Dr James Abangma.)The poet uses a series of images to reinforce his ideological posture. For example, the poet uses a beast-like image like "Occult-cannibalism", and other images like "Gaullist galley", "sword "and "bullet" to attest the oppressive administrative apparatus put in place in the university of Buea.

There is a clear philosophy behind these images of repression and resistance. First, they are concrete images which bespeak a materialist non-metaphysical conception of life and social struggle. Secondly, through these images the poet proclaims the Marxist philosophy of the dignity of labour, the centrality of work in any endeavour to wage a revolution or to embark on a programme of development. The poet concludes that these lecturers who yesterday pretended to be radical and revolutionary now understand only the language of "SILENCE, SUBMISSION, and COLLABORATION. (24) These words written all in capital letters emphasize the emasculation and stifling of intellectuals in the academia. The poet insinuates that university lecturers who are position-driven end up being gagged and stifled as they become either mute on certain critical issues that affect the nation's health, or they become very submissive to wrong decisions taken by hierarchy because they do not want to lose their 
positions. Because they are ambitious, they tend to collaborate with the despoilers of the nation's wealth and those who try to depersonalize lecturers with critical minds and perspectives.

The torments and frustrations of the masses and lecturers depicted in the two poems above are evidence that they do not belong, consequently do not have any socio-political and cultural identity. All the efforts made by the masses and lecturers to alleviate their conditions symbolize a pathetic quest for identity, for purpose, for destiny and for essence and existence.

The second thematic concerns that these two poets have treated in their collections are power, alienation and social exclusion.

\section{Power, Alienation and Social Exclusion}

Because the art (all art)... stands in eternal opposition to the dehumanization which tyranny and private property constitute, the poet tends to turn his back on his ruling and propertied colleagues and instead pitches his tent with the people in their struggle for justice and human existence. Thus, in situations requiring direct involved heroic intervention in defense or pursuit of progressive values, poets have often found themselves fighting on the side of the people. (Chidi Amuta, 1989:177)

The way power is structured in the African contemporary societies would reveal that a particular class is completely excluded from the scheme of things. Because they are socially excluded, they are physically and psychologically alienated. The above themes are succinctly treated in Gwangwa'a's "Who are we?" and Besong's "Their Champagne Party Will End" and "The Party's Over". The three poems, as would be seen in their analyses are a demonstration of the aspirations, hopes and interests of the people in a given historical stage, and as such maintain a certain relationship with the politics of exclusion and the sense of not belonging-alienation.

In Gwangwa'a's "Who are we?" the poet undertakes a socio-political epic journey and raises seven fundamental questions that revolve around self-definition and the quest for identity. Although these questions sound rhetorical, they are thought-provoking and mind-searching as they are intended chiefly to debunk the socio-political ills, conscientise and galvanize the socio-political consciousness of the oppressed masses. The poem touches on the rigging of elections and the rejection of the leader, the destruction of the Cameroonian ecosystem, the rape of people's wives by law enforcement officers, reduction of civil servants' salaries and capital flight. The poet is worried that all these are happening before the very eyes of the very people who are depressed, dejected and depersonalized. Though they protest somehow, the poet thinks they have not done enough since the leader still imposes himself on the people. The poet quips:

\section{He's been vomited out}

The blind and the lame shout

In bitter refusal of his rule

He forces himself to rule. (17)

The rigging of elections in contemporary African countries is legion. Elections results are known before Cameroonians/Africans ever go to the polls. The victory of the incumbent is a predictable certainty. The president having rigged elections in this particular poem now 
imposes himself on the people. Even those who are metaphorically blind and lame oppose this usurper who wants to administer by force.

Gwangwa'a again decries the wanton destruction of Cameroon's natural greenery and its forests. The poet/persona bemoans the fact that "We continuously watch our forests' rape/Without a blink and say we've no stake" (17). The metaphor of the rape of the forest underscores and brings out the brutality and wanton destruction of Cameroonian natural forests by the erstwhile masters:

If we see the timber passing

We accept, applaud and do nothing

Who are we? (17)

The rape imagery also emphasizes the brutality of the administration symbolized by the law enforcement officers. There is a link between the rape of innocent people's wives in the poem by law enforcement officers and the rape of the forests by Western imperialist countries:

If husbands watch the contemptuous

Rape of their wives by pseudo law

Enforcement bandits, without remorse,

Then who are we? (17)

The law enforcement officers who are to reinforce the law are those who pervert it. The poet describes them as "bandits and "pseudo law" enforcement officers. He sees the destruction of the ecosystem in the light of rape:

We continuously watch our forests' rape

Without a blink and say we've no stake. (17)

The rape image/symbol is a pivotal one in this particular poem. In biological science, plants emit oxygen which is taken in by human beings for their existence, and the carbon dioxide sent out by human beings is consumed by plants for their own survival. This is a symbiotic relationship that is of mutual benefits to both plant and man. The destruction of this relationship is tantamount to rape and even murder, the poet seems to be saying.

Economic hardship which is accentuated by the salary cuts that took place in Cameroon twice, in 1992 and 1993 did not mean anything for this docile breed of people. Twice the salaries of civil servants in Cameroon were slashed, and twice they did not protest:

Servants of the civil status

Are unable to support themselves

Salaries decrease at an untamed velocity,

And pains of devastation are still fresh

They accept with inward tears.

Who are we? (18)

Historically civil servants in Cameroon suffered two salary cuts in the early 90s without any protest. This act of the government reduced civil servants to professional beggars. But what is particularly lamentable is the fact that they did not react. Besides this, the poet is worried about the harassment and brutality of law enforcement officers of innocent and arm-less 
citizens:

We watch grenades and bullets hauled

At our armless wives and children

Who deserve our protection

Not forth coming

Who are we? (17)

With all these frustrations, delusion and defeats of life, it is evident that the ruling class uses its power to marginalize and socially isolate the populace. From this perspective, there are legitimate grounds for rejecting the policy of the neocolonial rulers who perpetrate and perpetuate the plight and predicament of the masses. "Life on our ancestral land/Has become very unbearable/Not of our making". The tragic experience of the masses in Cameroon in this particular poem illustrates the nonchalant attitude of the neocolonial rulers toward the ruled. From this perspective, it could be said that the strength of Gwangwa'a as a poet lies in the convincing manner in which he records the tragic experiences of the Cameroonian masses, the frankness with which he analyses the plight, frustrations and the contradictions of his society and the ideological clarity that informs his vision. His style is simple and yet forceful.

Besong too is another poet whose ideological orientation is similar to Gwangwa'a. In "Their Champagne Party Will End" and "The Party's Over", he demonstrates a progressive attitude to the political scene in post-independent Cameroon. The poet asserts that the mismanagement and squandermania of the ruling class will one day end. This is a common feature that binds third generation Anglophone Cameroonian writers: conscientisation, optimism and hope. Although the masses are excluded from the mainstream of power, the poet does not doubt the fact that the present obnoxious system will one day end. In "Their Champagne Party Will End" for instance, he authoritatively states:

For sure there is evidence that they could bomb

our towns and playgrounds with warheads;

containing irradiated nuclear wastes and bubonic

plagues (if we apprehend them).

There is evidence that this will be provided

by their reactionary comrades after Benghazi

But surely, their champagne party will end. (Disgrace, 2007:90)

The poet insinuates that in the present circumstances, uneasy consciences are caught in their own contradiction. African neo-colonial leaders are noted for their repression, brutality and political victimization, but a poet like Besong thinks that this is ephemeral. The poet is disturbed by the fact that although numerous deaths of workers are reported due to over work, the ruling class is swimming in the cesspool of ill-gotten wealth. The ruling class uses the state's money to organize meaningless and useless parties. The poet brings out the repressive and the exploitative tendencies of the ruling class. He debunks the myth that the neocolonial leadership is a Messiah that has come to deliver the oppressed from bondage. He intimates that a good political system must be organically evolved from the people's culture rather than be derivatively bound to the apron-strings of the foreign mentor of neocolonialism which 
only excludes the masses from socio-political affairs. To Besong, the kind of society he would like to see established in Cameroon is nevertheless a strong element of commitment to an important and progressive cause especially as the producers of the country's wealth are not adequately compensated:

Dead after day.

When our workers died of chronic shortages

Of overwork and exposure

It was fashionable for the repulsive old creeps;

With large baskets of cash

To give their champagne parties in open defiance of the

Victims they had exploited wretched. (Disgrace, 2007:88)

He equates the neo-colonial administration to occultism. The poet places a curse on these corrupt and occultist leaders:

Indeed, they have sworn fealty to their masonic lodges

And to each other to bankrupt our national coffers

The curse on the heads of the corrupt banditti. (Disgrace..., 2007:88)

Besong perceives neo-colonialism as a secret cult/society, which has vowed to rob and empty the national treasury. All the money gotten from the mineral resources and oil ends up in their private pockets and bank accounts at home and abroad. This system is void of faith, hope and love which the poet thinks African cultural values incarnate:

We have watched our oil bonuses spreading

along their cobbled facades;

the posh suburbs neighbouring the foreign multinational warehouses on the coast

where, the arriviste-factor looking frightened behind

the wheel of his chocolate citroen-maserati

hurries home to his plastic daughter. (Disgrace, 2007:89)

The poet makes use of three poetic devices to good effect: alliteration, repetition and symbolism. The poet describes the alacrity with which these embezzlers rush with the stolen money realised from the oil bonuses as: "hurries home to his plastic daughter". These alliterative words, "hurries", "home" and "his" (h, h, h,) reinforce the speed with which public finances are siphoned and stored in private accounts abroad. Again, the poet repeats the sentence. "Their Champagne party will end" four times in the poem. This repetition, which is a poetic device par excellence, emphasizes the poet's optimism and hope. To the poet, neo-colonialism symbolises occultism because most of the members of government belong to a secret cult or freemason. "Indeed, they have sworn fealty to their masonic lodges", echoes occultism.

In "Their Champagne party will end", Besong makes rather a depressing interpretation of the Cameroonian society. There is too much said about the tragic side of life and little about the joys and delights of living in this society. It is clear from the reading of this poem that misery 
and tragedy are a fact of life in the Cameroonian society.

Besong's ideological consciousness is again re-echoed in “The Party's Over!” (Written after the solemn Declaration of November) This is a poem which expresses the same revolutionary aesthetics as "Their Champagne party will end". The poem was written after Cameroon's first president, Amadou Ahidjo's declaration on the 4th of November 1982 that he would hand the baton of command to his groomed successor, Paul Biya. Ahidjo's resignation was received with a lot of mixed feelings. The poet thought that a new dawn had come. Norbert Mbulai in his article entitled "Satire and Historicity in the Poetry of Bate Besong" argues that,

'The Party's over' is more of an occasional poem, composed as the note after the title indicates, after the solemn declaration of November, that is, November 4, 1982. It is then a hot poetic reaction to Ahidjo's announcement to quit the political scene, after close to twenty five years on the helm, and as his constitution had stipulated, hand over power to his groomed successor, Paul Biya. What is interesting here is the poet's being taken in by the general wave of optimism that swept over the country at what appeared then to be a pivotal moment in its short post-independence history (qtd in Chia and Azeyeh, (eds), 2008:135).

Besong exposes the human condition of the oppressed masses by educating the people on the societal ills. This critical consciousness can result in the transformation of the society which can provide both individual and collective fulfilments to those whose identity has been compromised. In other words, the awakening of this consciousness which is what the poet is doing can lead to social discontent. When Besong decries the mismanagement of state's resources, he is portraying how the masses are politically victimized and socially excluded from the sharing of the nation's wealth and power.

To conclude this section, it is important to underscore the fact that in oppressive and repressive situations like the one in Cameroon, the poet who lends his art to the service of freedom, justice and democracy restates the truism that socially redeeming political action is the highest form of artistic expression. After all, a poet must be socially committed in order to be universally engaged.

The last thematic concern that this article preoccupies itself with is the role of violence in nation- building.

\section{The Rhetoric of Violence and Nation-building}

Violence in order to change an intolerable, unjust oppressive social order is not savagery; it purifies man. Violence to protect and preserve an unjust oppressive social order is criminal and diminishes man. (Ngugi wa Thiong'o, 1972:28)

Besong and Gwangwa'a in some of their poems have demonstrated their sense of patriotism which is perceived only in the activist and combatant dimension of their commitment. The two poets depict violence as an inevitable part of their affection and patriotism to their nation. In "If an Anglophone Must Die" and "Ntarikon Massacre, 1990", by Gwangwa'a and Besong respectively, these two poets demonstrate that violence is a crucial imperative needed in resolving some of the essential contradictions in the Cameroonian society.

In the poem "If an Anglophone must Die" written in the tradition of the African-American poet, Claude McKay, the poet brings out the violence that permeates and pervades the 
Cameroonian body politic. The Francophone Cameroonians who wield both political and economic powers do not see the Anglophone Cameroonians as human beings. They are politically marginalized, socially isolated and economically exploited. It is against such an ugly backdrop that the poet suggests and insinuates that only violence can resolve this conflict and contradiction.

Andrew T. Ngeh in his article "Socialist Realism and the Dialectics of Violence in Anglophone Cameroonian Drama: Bate Besong and Bole Butake's Dramatic Vision" while quoting Wole Soyinka and Ngugi Wa Thiong'o to reinforce the moral justifications of violence points out that the term violence happens to be a moral concept. Questions asking for explication and elucidation of the causes of violence in a nation's consciousness are legitimate"... (99). Ngugi wa Thiong'o in Homecoming makes a distinction between two types of violence when he argues, "Violence in order to change an intolerable, unjust social order is not savagery; it purifies man. Violence to protect and preserve an unjust oppressive social order is criminal and diminishes man" (28). It is the former type of violence which Soyinka terms "proletarian violence". (98) He avers, "... nothing can be more proletarian than violence: violence, we know is one of the few universal commodities; unlike rice, it cannot be placed under license. Even so, I wish to stress that violence has to be produced" (98).

In "If an Anglophone must Die" Gwangwa'a writes:

If an Anglophone must die, let it be a noble death

So that his precious blood is not spilled in vain.

Let no scream be heard in the final glimpse and breath

Though, by grenades, he suffers much in utter pain. (46)

The poet exhorts the oppressed Anglophone Cameroonians not to give up but to press on with their quest for freedom, liberty, justice and genuine democracy. In spite of the repression of armed tyranny, "Though, by grenades, he suffers much pain", hope and optimism emerge as the dominant theme in the poem. The constant reaffirmation of optimism and faith in the future is not just an anodyne to drown the pangs of present adversity but a way of imbuing the sacrifices implicit in the struggle for freedom with a sense of purpose. The poet states:

Anglophones! Fiercely! Face whatever be the attack;

When helmed in a corner, die fighting back,

Those who survive the fight of your might

Will lead the rest with your fight. (46)

The poet cherishes freedom, not for its own sake but in the context of his people's struggle to regain their dignity and identity after years of humiliation and denigration. That is why he exhorts Anglophone Cameroonians to use violence to regain their lost liberty and freedom because violence has some moral justifications. The poet laments a certain sense of alienation from his people, an alienation which finds concrete expression in the recurrent longing for justice and freedom. "If an Anglophone must Die" constitutes a bold challenge to the Francophone dominant dictatorial system. There is no lamentation for the victims of the brutal system, no sense of self-pity, but a refusal to accept subjugation and domination by the 
Francophone Cameroonians who wield and control political power.

Besong too in "Ntarikon, Massacre, 1990" brings out the concept of violence which is perceived as a means to effect positive change. In this two stanza poem, the poet relates an unfortunate incident that occurred in Ntarikon, in Bamenda in the North West Region of Cameroon on the 26th of May 1990 when the Social Democratic Front party (SDF) was launched which resulted in the death of six innocent Cameroonians. They were shot and killed in cold blood by the oppressive gendarmes of Paul Biya. The poet bemoans the fact these young men who were killed had a bright and promising future which was cut short:

the blood is still fresh

on the slabs, the morgues

are wet

for those whose

tomorrows

are now shards of broken

glass. (59)

This particular poem is characterized by a general contemplative tone which is shrewd in its attempt not to compromise the organic proxity between the poet and his people. Consequently, it brings out the emotions which permeate and exude patriotic and heroic identification with those who bear the burden of oppression as the blood of the oppressed is "still fresh/on the slabs, the morgues/are wet". Besong seems to have some regrets about the outcome of what these freedom fighters fought and died for, hence: tomorrows/are now shards of broken/glass.

The shattered glass is a dense symbol with metaphoric possibilities. It brings out the brutality of neocolonialism and the frustrated dreams of the struggling people. Furthermore, the shattered glass symbolizes the violence exerted on the struggling people and their reactions to this violence which resulted in their deaths.

The efficacy of the poet's diction reinforces his ideological preoccupation. Words and phrases like: "blood", "slabs", "morgues" and "shards of broken/glass" bring to mind very frightful images. These are images of death, dearth, decay and lack of fulfillment. Even though the expectations of these freedom fighters have been cut short, it could be argued that their blood watered and nurtured the tree of freedom. Thus, their fall depicts the dialectical relationship between the eventual defeat of the oppressor and the ultimate victory of the oppressed. Historically, this can be explained by the proliferation of other opposition political parties that emerged after the Social Democratic Front party. Paul Biya and his CPDM party were not comfortable with the existence of other political parties. The Social Democratic Front party opened the floodgate for other opposition parties that challenge the oppressive regime of Paul Biya.

\section{Conclusion}

In conclusion, it is important to restate the hypothetical contention of this paper. This paper argued that Bate Besong and Gahlia Gwangwa'a in their poetry have brought out the misuse 
of power in African governments. To these poets, this has resulted in tension, confusion, contradiction, alienation and social exclusion. The rhetoric of violence and the conscientisation of the populace become a categorical imperative in their poetic vision. Hexis and praxis underline their poetry. Consequently, the paper concludes that violence is crucial in bringing about positive change in any society since change and development are the fundamental hallmarks of dialectics. In this case the violence of the oppressed with all its moral justification can effect a positive change in the society.

\section{References}

Amuta, C. (1989). The Theory of African literature. London: Heinemann.

Barry, P. (1995). Beginning Theory. Manchester: Manchester University Press.

Besong, B. (2007). Disgrace: Autographical narcissus. Limbe: Design House.

Fonlon, B. (Ed.). (1982). The Idea of Literature. Abbia. Yaoundé: CEPER.

Gorky, M. (1971). On Socialist Realism. In G. V. James (Ed.), Socialist Realism in Literature and Art: A collection of articles (pp. 32-54). Moscow: Progress Publishers. http://www.l.evengenvaertcentre.be/

Mbulai, K. (2008). "Satire and Historicity in the Poetry of Bate Besong". Epasa Moto: A Bilingual Journal of Arts, and Letters and the Humanities, 3(2), 124-142.

Ngeh, A. (2012). "Socialist Realism and the Dialectics of Violence in Anglophone Cameroonian Drama: Bate Besong and Bole Butake's Dramatic Vision". In Lakshmi Krishhan, Bhavatesh Guru et al. (Eds). Creative Forum, New Dehli.

---(2013) "Language and Commitment in Anglophone Cameroonian Poetry: The Poetic Vision of Three Anglophone Cameroonian Poets". In Inge Kosch (Ed.), South African Journal of African Languages (SAJAL). (pp.107-114)

Ngugi wa Thiong'o. (1972). Homecoming. London: Heinemann.

Nuruddin, F. (1993). The Creative Writer and the African Politician. The Guardian, Lagos, 9 September, (p. 11)

Mphahlele, E. (1974). The African Image. London: Faber and Faber.

Little, W., \& Fowler, H .W. (1961). The Oxford Universal Dictionary. London: Clarendon Press.

\section{Copyright Disclaimer}

Copyright reserved by the author(s).

This article is an open-access article distributed under the terms and conditions of the Creative Commons Attribution license (http://creativecommons.org/licenses/by/3.0/). 